\title{
Dietary modification of potential vitamin $K$ supply from enteric bacterial menaquinones in rats
}

\author{
BY J. C. MATHERS \\ Department of Agricultural Biochemistry and Nutrition, University of Newcastle, \\ Newcastle upon Tyne NE1 $7 R U$ \\ AND FRESIA FERNANDEZ AND M. J. HILL \\ Bacterial Metabolism Research Laboratory, PHLS Centre for Applied Microbiology \& Research, \\ Porton Down, Salisbury, Wiltshire SP4 OJG \\ AND P. T. MCCARTHY AND M. J. SHEARER \\ Haematology Research Laboratory, Guy's Hospital, London SE1 9RT \\ AND A. OXLEY \\ Department of Haematology, Royal Victoria Infirmary, Newcastle upon Tyne \\ (Received 17 February 1989 - Accepted 30 November 1989)
}

\begin{abstract}
Rats given a low-fibre diet based on boiled white rice developed symptoms of severe vitamin $K$ deficiency within $23 \mathrm{~d}$. Inclusion of autoclaved black-eye beans (Vigna unguiculata) in the diet prevented the bleeding syndrome. To test the hypothesis that deficiency resulted from low phylloquinone intake exacerbated by inadequate production of menaquinones by the enteric bacteria, a follow-up experiment was carried out in which groups of rats were given an all-rice diet, a rice + beans diet or a stock diet. Rats on the allrice diet had significantly lower faecal concentrations of the main menaquinone-producing bacterial species (Bacteroides fragilis and Bacteroides vulgatus) than animals on either of the other two diets. This coupled with the much lower faecal output on this diet suggests that total menaquinone production was low for the all-rice diet. The alterations in faecal flora were associated with several significant changes in caecal metabolism. Rats given the stock diet had much shorter caecal transit times and a considerably greater proportion of butyric acid in volatile fatty acid end-products than did rats on either of the other two diets.
\end{abstract}

Caecal fermentation: Menaquinones: Vitamin K: Rat

Phylloquinone (vitamin $K_{1}$ ) from green leafy vegetables is the main dietary source of vitamin $\mathrm{K}$ required for the post-translational carboxylation of glutamate residues to produce $\gamma$-carboxyglutamic acid (Gla) in at least seven plasma proteins, four of which are involved in blood clotting. Vitamin K-dependent Gla-containing proteins are also present in bone (osteocalcin), kidney, atherosclerotic plaque and several other tissues (Suttie, 1985). Adult man appears to be very resistant to the development of a primary deficiency of the vitamin (Suttie, 1985), but haemorrhagic disease of neonates is occasionally reported and seems to be more common in breast-fed than bottle-fed infants (von Kries et al. 1988). Some species of enteric bacteria produce menaquinones (vitamin $\mathrm{K}_{2}$; Collins \& Jones, 1981) having activity as vitamin K (Suttie, 1985) and such menaquinones are frequently assumed to provide about half the human requirement (Passmore \& Eastwood, 1986). In vitro studies using everted rat colonic sacs have shown that menaquinones may be absorbed by a passive non-saturable process (Hollander et al. 1976), but whilst menaquinones have been detected in liver from many species including man (Suttie, 1985) there is no 
Table 1. Expt A. Composition of experimental diets $(\mathrm{g} / \mathrm{kg})$

\begin{tabular}{lrrrr}
\hline Experimental diets ... & 2A & $3 \mathrm{~A}$ & $4 \mathrm{~A}$ & $5 \mathrm{~A}$ \\
\hline Rice & 750 & $637 \cdot 5$ & 525 & $412 \cdot 5$ \\
Beans & 0 & $112 \cdot 5$ & 225 & $337 \cdot 5$ \\
Casein +methionine $\dagger$ & 120 & 100 & 80 & 60 \\
Sucrose & 30 & 50 & 70 & 90 \\
Maize oil & 50 & 50 & 50 & 50 \\
Vitamin + mineral premix $\ddagger$ & 50 & 50 & 50 & 50 \\
\hline
\end{tabular}

* Black-eye beans (Vigna unguiculata) cooked and ground.

+ Casein-methionine $(100: 1, \mathrm{w} / \mathrm{w})$.

$\$$ Contained (g/kg premix): $\mathrm{CaHPO}_{4} 350, \mathrm{MgSO}_{4} \cdot 7 \mathrm{H}_{2} \mathrm{O} 60, \mathrm{NaCl} 15, \mathrm{KCl} 95, \mathrm{FeSO}_{4} \cdot 7 \mathrm{H}_{2} \mathrm{O} 3, \mathrm{MnSO}_{4} \cdot 4 \mathrm{H}_{2} \mathrm{O}$ 4, $\mathrm{ZnSO}_{4} .7 \mathrm{H}_{2} \mathrm{O} 4 \cdot 5, \mathrm{CuCl}_{2} .2 \mathrm{H}_{2} \mathrm{O} 0 \cdot 27, \mathrm{KIO}_{3} 0 \cdot 005$; and (mg/kg premix): Rovimix $\mathrm{AD}_{3} 500 / 100$ (Roche) 200 , Rovimix E50 Adsorbate (Roche) 1200, folic acid 15, riboflavin 60, thiamin hydrochloride 90 , pyridoxine hydrochloride 75 , choline chloride 27000 , calcium pantothenate 50 , biotin 20 , cyanocobalamin 1 in a sucrose base.

information on rates of menaquinone production or absorption in vivo. Vitamin $\mathrm{K}$ deficiency in breast-fed babies may result from limited transfer of the vitamin across the placenta (Shearer et al. 1982), relatively low concentrations of phylloquinone in breast milk (Haroon et al. 1982) and the development of a gut flora in which bacteria devoid of menaquinones, e.g. bifidobacteria and lactobacilli, predominate (Bullen et al. 1977).

Administration of antibiotics to vitamin K-deprived human subjects (O'Reilly, 1971; Allison et al. 1987) and rats (Black et al. 1942) has been used to produce vitamin K deficiency but the effects of dietary modification on the metabolic activities of the large intestinal flora are poorly understood and there is no quantitative information on the ways in which such modification may influence the contribution made by enterically produced menaquinones in any species. In the first experiment reported here, vitamin $\mathrm{K}$ deficiency occurred in rats within $23 \mathrm{~d}$ of giving a diet based on boiled white rice. The follow-up experiment was designed to investigate the potential for dietary manipulation of the large intestinal population of menaquinone-producing bacteria. Findings on the fermentation characteristics accompanying such changes are also presented.

\section{EXPERIMENTA L}

Expt $A$

Animals and housing. Male Wistar rats, initial weight approximately $150 \mathrm{~g}$, were purchased from A. Tuck \& Son, Battlebridge, Essex and housed initially in plastic cages with wiremesh floors (three per cage) and fed on a stock diet (41B, Oxoid Ltd, Basingstoke, Hampshire) ad lib. until they weighed 234 (SD 9.5)g. Twenty rats were then housed individually in Perspex and stainless-steel metabolism cages (Thompson, 1970) with expanded metal floors (experimental diet-fed animals). The animal room was maintained at a temperature of $25 \pm 1^{\circ}$ and a relative humidity of $53 \pm 0.5 \%$.

Diets. Four experimental diets $(2 \mathrm{~A}-5 \mathrm{~A})$ containing various proportions of polished rice (Oryza sativa) and black-eye beans (Vigna unguiculata) were formulated (Table 1). The protein contents of the diets were kept approximately constant (Matschiner \& Doisy, 1965) at about $185 \mathrm{~g} / \mathrm{kg}$ dry matter by varying the proportions of casein + methionine and of sucrose. Before inclusion in the diets, the rice was cooked by boiling in open pans for $10 \mathrm{~min}$ and the beans soaked in hot water for $40 \mathrm{~min}$ and autoclaved at $115^{\circ}, 69 \mathrm{kPa}(10 \mathrm{psi})$ for $15 \mathrm{~min}$. The cooked rice and beans were dried at $60^{\circ}$ and ground through a $1 \mathrm{~mm}$ screen. The experimental diets were offered at $15 \mathrm{~g}$ air dry weight/d. For comparative 
purposes, samples of liver and blood were also obtained from rats of the same strain and from the same supplier and given access ad lib. to a commercially prepared pelleted chow (41B, Oxoid Ltd). Water was available ad lib. to all animals.

Experimental procedures. Groups of five rats were given each of the experimental diets for $25 \mathrm{~d}$ after which time survivors were killed by diethyl ether inhalation. Blood was collected by cardiac puncture and $2-\mathrm{ml}$ portions were transferred into tubes containing $0.2 \mathrm{ml} 0.15 \mathrm{M}$-sodium citrate solution for prothrombin clotting time and other assays. Animal carcasses were stored at $-20^{\circ}$ until required for analyses. Stock-fed rats were killed at intervals either by chloroform inhalation (when livers only were required) or diethyl ether inhalation (when blood samples were required); the caecums were removed for other purposes and the carcasses stored at $-20^{\circ}$ until required for analysis.

Analytical methods. Platelet-poor plasma was prepared by centrifuging citrated blood at $2000 \mathrm{~g}$ for $5 \mathrm{~min}$ and assayed for prothrombin clotting time and blood clotting factors II, V, VII, IX and X using methods described by Paul et al. (1987). Values for clotting factors are expressed as percentages of a control pooled human plasma with a prothrombin time of $12 \mathrm{~s}$. For liver analyses, frozen carcasses were allowed to thaw sufficiently to permit removal of the livers which were washed in ice-cold saline $(9 \mathrm{~g}$ sodium chloride $/ 1)$, blotted dry, weighed and transported packed on dry ice. Lipids of rat diets and livers were extracted with acetone and partitioned into hexane as previously described (Shearer, 1986a). Phylloquinone (vitamin $\mathrm{K}_{1}$ ) was measured in lipid extracts by a multi-stage purification procedure with final analysis by high-performance liquid chromatography and dualelectrode electrochemical detection in the redox mode (Hart et al. 1985; Shearer, 1986 b). Quantification of phylloquinone was made by the method of internal standardization using menaquinone- 6 as the internal standard for diet analyses and $2^{\prime}, 3^{\prime}$-dihydrophylloquinone for liver analyses. Post-mortem investigation including histology was carried out by standard procedures on three rats given the all-rice diet (diet $2 \mathrm{~A})$.

\section{Expt $B$}

Eighteen male Wistar rats (mean initial weight $211 \mathrm{~g}$ ) were placed in individual steel and Perspex metabolism cages (Thompson, 1970) fitted with glass separators to permit collection of urine and faeces.

Diets and feeding. Three diets were used. Diet $1 \mathrm{~B}$ was a stock diet (Oxoid 41B) milled to pass a $1 \mathrm{~mm}$ screen and containing $2 \mathrm{~g}$ chromic oxide $/ \mathrm{kg}$ as an indigestible marker. Diets $2 \mathrm{~B}$ and $5 \mathrm{~B}$ were formulated as for diets $2 \mathrm{~A}$ and $5 \mathrm{~A}$ in Expt $\mathrm{A}$ but with the addition of $0.5 \mathrm{mg}$ menadione (a synthetic source of vitamin $\mathrm{K}$ ) and $2 \mathrm{~g} \mathrm{Cr}_{2} \mathrm{O}_{3}$ (an unabsorbed marker) $/ \mathrm{kg}$ at the expense of sucrose (National Research Council, 1978). Six animals were allocated to each diet and each was offered $15 \mathrm{~g}$ diet once daily at 10.00 hours. Water was available ad lib.

Experimental procedures. Rats were weighed on days 1, 15, 24, 25 and 26. After $14 \mathrm{~d}$ adaptation to diets, complete collections of urine and faeces were made for $7 \mathrm{~d}$. Food residues over the latter period were collected, dried and weighed. On each of days 24,25 and 26 , freshly voided faeces were collected by picking up each rat by the tail which provoked defaecation. Approximately $0.5 \mathrm{~g}$ freshly voided faeces was immediately transferred into a pre-weighed bottle containing $4.5 \mathrm{ml}$ Glycerol Transport Broth (100 $\mathrm{g}$ glycerol/1, Lab-Lemco, Oxoid Ltd). It was suspended in this fluid by breaking up the pellet with a mounted steel needle followed by 'whirli' mixing, and stored at $-80^{\circ}$. Between 13.00 and 17.00 hours on day 26 , rats were anaesthetized by diethyl ether inhalation, laparotomy was performed and samples of blood withdrawn from the portal vein and heart. The liver was excised, rinsed in ice-cold saline, blotted dry, weighed and stored at $-80^{\circ}$. The gastrointestinal tract was removed and the caecum excised and weighed. The $\mathrm{pH}$ of the 
caecal contents was measured and duplicate samples (approximately 0.5 g) were mixed 2:1 $(\mathrm{w} / \mathrm{v})$ with deproteinizing solution (metaphosphoric acid solution $(200 \mathrm{~g} / \mathrm{l})$ containing $50 \mathrm{~mm}$-3-methyl-valeric acid). Further samples of caecal contents were transferred into preweighed tubes for determination of dry matter (DM) and $\mathrm{Cr}_{2} \mathrm{O}_{3}$ contents. The caecal tissue was washed, blotted dry and weighed.

Chemical analyses. Volatile fatty acids (VFA) in caecal contents were measured by gas-liquid chromatography using a $2 \mathrm{~mm}$ internal diameter column packed with $10 \% \mathrm{SP}$ 1200-1\% phosphoric acid on 80/100 Chromosorb (Supelco Inc., Belliforte, Pa 16823, USA) in a PU 4550 gas-liquid chromatograph (Pye Unicam, Cambridge). Samples (100 mg) of foods, caecal contents and faeces were weighed into graduated Pyrex tubes and ashed at $450^{\circ}$ for $16 \mathrm{~h}$. The residue was digested using $1.2 \mathrm{ml}$ acid mixture $(300 \mathrm{ml}$ $\mathrm{MnSO}_{4} \cdot 4 \mathrm{H}_{2} \mathrm{O}$ solution $(100 \mathrm{~g} / 1)$ diluted to 1 litre with orthophosphoric acid) and $1.6 \mathrm{ml}$ potassium bromate solution $\left(45 \mathrm{~g} \mathrm{KBrO}_{3} / 1\right)$ and made to $10 \mathrm{ml}$ with distilled water. To portions of the digest, $1 \mathrm{ml}$ calcium chloride solution $\left(5 \cdot 47 \mathrm{~g} \mathrm{CaCl}_{2} \cdot 6 \mathrm{H}_{2} \mathrm{O} / \mathrm{l}\right)$ and $0 \cdot 1 \mathrm{ml}$ sodium silicate solution $\left(7.55 \mathrm{~g} \mathrm{Na}_{2} \mathrm{SiO}_{3} .5 \mathrm{H}_{2} \mathrm{O} / 1\right)$ were added and, after appropriate dilution, the chromium concentration was measured by atomic absorption spectrophotometry (SP9; Pye Unicam, Cambridge).

Bacteriology. Bacteriological analyses of the faecal samples were performed by the method of Borriello et al. (1978). In this method the media are pre-reduced and stored anaerobically before use. All dilutions and plating techniques were carried out in an anaerobic chamber. Qualitative and quantitative analysis were performed using a range of selective and non-selective media which enabled enumeration of aerobic, microaerophilic, obligate and facultative anaerobic organisms. Identification of the organisms was confirmed by the method of Holdeman et al. (1977), whilst facultative organisms were identified by the method of Cowan \& Steel (1965). The counts of colony-forming units per $\mathrm{g}$ of faeces were expressed as $\log _{10}$ counts $\left(\log _{10} \mathrm{cfu} / \mathrm{g}\right)$.

\section{Statistical analysis}

Values from both experiments were examined by one-way analysis of variance. In Table 2, data for stock-fed rats were not included in the analysis of body masses. For faecal bacteriological values in Expt B (see Table 7, p. 647), where measurements were made for each animal on each of the $3 \mathrm{~d}$, means for each animal were computed and used in the analysis of variance. Variation between days within animals will be discussed elsewhere. For Expt A, linear regression was used to describe the relationship between liver phylloquinone concentration and concentration of phylloquinone in the diet. For Expt B, differences between treatment means were tested using the following orthogonal contrasts:

contrast 1: $\operatorname{diet} 1 \mathrm{~B} v$. (diet $2 \mathrm{~B}+\operatorname{diet} 5 \mathrm{~B})$,

contrast 2: $\operatorname{diet} 2 \mathrm{~B} v$. diet $5 \mathrm{~B}$.

\section{RESULTS}

Expt $A$

Animal health. All the rats on the experimental diets ate normally and grew well (Table 2) over the first $15 \mathrm{~d}$ of the study. Thereafter, whilst rats on diets containing beans appeared normal, those given the all-rice diet (diet $2 \mathrm{~A}$ ) began to show signs of ill-health. Reduced food intake was the earliest symptom and was first observed 16-23 d after introduction to the experimental diets. Faeces became malformed with some scouring. The rats became moribund and the first (rat no. 20) died on day 18. Rat no. 14 haemorrhaged from the right paw on day 20 and was killed by chloroform inhalation. Rats on the all-rice diet showed 
Table 2. Expt A. Body mass, growth rate, faecal dry matter ( $D M$ ) output, liver mass, liver lipid concentration and concentrations of vitamin $K_{1}$ (phylloquinone) in the food and livers of rats given the stock diet and experimental diets containing various proportions of black-eye beans (Vigna unguiculata) and rice

(Values are means with pooled standard error for five rats per group)

\begin{tabular}{|c|c|c|c|c|c|c|}
\hline \multirow[b]{2}{*}{ Diet* $^{*} \ldots$} & \multirow[b]{2}{*}{ Stock $1 \mathrm{~A}$} & \multicolumn{4}{|c|}{ Experimental } & \multirow[b]{2}{*}{$\operatorname{SE}(n 5)$} \\
\hline & & $2 \mathrm{~A}$ & $3 \mathrm{~A}$ & $4 \mathrm{~A}$ & $5 \mathrm{~A}$ & \\
\hline Body mass (g) & 698 & $293 \dagger t$ & 320 & 316 & 304 & $4 \cdot 7$ \\
\hline Growth rate $\$(g / 7 d)$ & - & $25 \cdot 3 \ddagger$ & $28 \cdot 4$ & $26 \cdot 2$ & $25 \cdot 0$ & $1 \cdot 27$ \\
\hline Faecal DM output $\S(g / 7 d)$ & - & $4.83 \ddagger$ & $4 \cdot 95$ & 6.28 & $7 \cdot 29$ & 0.149 \\
\hline Liver mass ( $\mathrm{g} / \mathrm{kg}$ body mass) & $44 \cdot 5$ & $40.4 \|$ & $38 \cdot 7$ & $41 \cdot 2$ & $40 \cdot 2$ & $1 \cdot 15$ \\
\hline Liver lipid ( $\mathrm{g} / \mathrm{kg}$ liver mass) & 24.9 & $26 \cdot 9 \|$ & $22 \cdot 3$ & $21 \cdot 2$ & $20 \cdot 6$ & 1.40 \\
\hline $\begin{array}{l}\text { Dietary vitamin } \mathrm{K}_{1} \\
(\mu \mathrm{g} \text { phylloquinone } / \mathrm{kg})\end{array}$ & 52 & 16 & 28 & 36 & 49 & - \\
\hline $\begin{array}{l}\text { Liver vitamin } \mathrm{K}_{1} \\
\text { (ug phylloquinone } / \mathrm{kg} \text { ) }\end{array}$ & $2 \cdot 58$ & $0 \cdot 14 \|$ & $0 \cdot 38$ & $0 \cdot 40$ & 1.29 & 0.583 \\
\hline
\end{tabular}

* For details, see Table 1 and p. 640.

$\dagger$ Measured on day 18 (rat nos. 5 and 20); day 25 for other rats on experimental diets.

\$ Three rats only (values for two rats which were unwell were excluded).

$\S$ Measured over days $11-18$.

$\|$ Two rats only.

a loss of the normal pink colour from the ears and other extremities and the remaining three rats on this diet were killed on days 18 (rat no. 5), 22 (rat no. 30) and 24 (rat no. 36). Postmortem investigations were carried out on rat nos. 5, 20 and 30 . Rat no. 20 had subcutaneous bruising and haemorrhages, the liver was very pale and the kidneys were congested. The urine was heavily blood-stained and contained a fibrin clot. The intestinal contents were mucoid and the large intestine was full of dark brown digesta. Cultures from a range of tissues showed a scanty growth of non-haemolytic coliforms only. Pathological findings in rat no. 5 were similar but less marked. The post-mortem appearance was similar to that in animals which had received an anticoagulant. Rat no. 30 did not show any of these symptoms at post-mortem.

\section{Vitamin $K$ status}

The measured vitamin $\mathrm{K}_{1}$ concentration in white rice was very low ( $2 \mu \mathrm{g}$ phylloquinone $/ \mathrm{kg}$ ) compared with that in the black-eye beans $(108 \mu \mathrm{g}$ phylloquinone $/ \mathrm{kg})$. Measured phylloquinone concentrations in the experimental diets $(2 \mathrm{~A}-5 \mathrm{~A})$ increased with increasing proportion of beans in the diet (Table 3), and were higher by $8-12$ (mean 10$) \mu \mathrm{g} / \mathrm{kg}$ than those calculated from the proportions of rice, beans and maize oil in the diets (assuming a value of $30 \mu \mathrm{g}$ phylloquinone $/ \mathrm{kg}$ oil obtained for a different batch of this ingredient). There was a significant $(P<0.05)$ positive relationship between the concentration of phylloquinone in the diet $(x)$ and liver phylloquinone concentration $(y)$ :

$$
y=-0.68(\operatorname{SE} 0.53)+0.037(\operatorname{SE} 0.014) x,(r 0.56, n 17) .
$$

Whilst the stock diet contained a concentration of phylloquinone similar to that of the diet containing the highest level of beans (diet 5A), the liver phylloquinone concentration from animals fed on the stock diet was much higher than that of those given the experimental diets. The mean hepatic vitamin $\mathrm{K}_{1}$ concentration of animals on the diet with the highest 
Table 3. Expt A. Prothrombin clotting times and concentration of some coagulation factors in plasma of rats given the stock diet and experimental diets containing various proportions of black-eye beans (Vigna unguiculata) and rice

\begin{tabular}{|c|c|c|c|c|}
\hline \multirow[b]{2}{*}{ Diet*... } & \multirow[b]{2}{*}{$\begin{array}{l}\text { Stock 1A } \\
(n 4)\end{array}$} & \multicolumn{3}{|c|}{ Experimental } \\
\hline & & $\begin{array}{c}2 \mathrm{~A} \\
\text { Rat no. } 36\end{array}$ & $\begin{array}{c}3 \mathrm{~A} \\
\text { Rat no. } 21\end{array}$ & $\begin{array}{c}5 \mathrm{~A} \\
\text { Rat no. } 3\end{array}$ \\
\hline Prothrombin clotting time (s) & $15(0 \cdot 9) \dagger$ & $>60$ & 24 & 15 \\
\hline \multicolumn{5}{|c|}{ Concentration of coagulation factors in plasmat } \\
\hline Factor II & $45(9 \cdot 1)$ & 5 & 8 & 52 \\
\hline Factor V & $110(11 \cdot 7)$ & 120 & 105 & 120 \\
\hline Factor VII & $124(11 \cdot 0)$ & 4 & 13 & 160 \\
\hline Factor IX & $40(9 \cdot 9)$ & $<1$ & 7 & 40 \\
\hline Factor $\mathrm{X}$ & $30(2 \cdot 4)$ & 1 & 4 & 33 \\
\hline
\end{tabular}

* For details, see Table 1 and p. 640.

+ Standard deviation of a single observation is given in parentheses.

‡ Expressed as a percentage of a control pooled human plasma with a prothrombin time of $12 \mathrm{~s}$.

level of beans (diet 5A) was only half that of the animals given the stock diet. Some of the differences in liver phylloquinone concentrations between stock-fed and experimental animals may be due to age or body-weight and further information in this area is required. The mean plasma prothrombin clotting times of stock-fed rats was $15 \mathrm{~s}$, and was the same as that observed for rats given diet $4 \mathrm{~A}(n 2)$ and diet $5 \mathrm{~A}(n 3)$. Rats given diet $3 \mathrm{~A}$ had prothrombin times of 16,17 and $24 \mathrm{~s}$, whilst the only animal (rat no. 36) tested from the all-rice-diet (diet 2A) group had a prothrombin time in excess of $60 \mathrm{~s}$. The plasma concentrations of coagulation factors for some rats are given in Table 3. Concentrations of factor V (non-vitamin K-dependent) were similar in all animals tested, but concentrations of the vitamin $\mathrm{K}$-dependent factors II, VII, IX and X were severely reduced in the rats with the longest prothrombin clotting times (and given diets $2 \mathrm{~A}$ and $3 \mathrm{~A}$ ) compared with stockfed rats or rat no. 3 which had been given the diet with the highest level of beans (diet $5 \mathrm{~A}$ ). Liver weights (as a proportion of body mass) were similar for rats given the experimental diets but significantly greater for those consuming the stock diet. Diet did not affect the concentration of lipid in the liver (Table 2).

\section{Expt $B$}

All animals remained healthy throughout the study. Food consumption was almost total with the difference in DM intake between diet $1 \mathrm{~B}$ and the other diets being due to the lower DM content of the stock diet (Table 4). The rats grew well on both rice-containing diets at nearly $6 \mathrm{~g} / \mathrm{d}$. The $27 \%$ lower growth for rats on the stock diet was as expected, since the DM intake was lower and DM digestibility considerably reduced (Table 4) on this diet. Faecal DM output (g/kg DM intake) was 5.9 and 3.5 times greater with diet $1 \mathrm{~B}$ than with diets $2 \mathrm{~B}$ and $5 \mathrm{~B}$ respectively. Liver weights (per unit body mass) were $10 \%$ greater for rats given the rice-containing diets than for those fed on the stock diet (Table 4).

\section{Caecal metabolism}

Rats given the very-low-fibre all-rice diet (diet 2 B) had caecums weighing only half that of rats given either of the other two diets (Table 5). These between-diet differences were also found in the mass of caecal tissue which on diet $2 \mathrm{~B}$ was only 0.72 of that on the stock and rice + beans diets. The proportion of $\mathrm{DM}$ in caecal contents was highest on diet $1 \mathrm{~B}$ and 
Table 4. Expt B. Food intakes and faecal outputs, growth rates and liver weights of rats given a stock diet and two experimental diets based on white rice with and without black-eye beans (Vigna unguiculata)

(Values are means with pooled standard errors for six rats per group)

\begin{tabular}{|c|c|c|c|c|c|c|}
\hline \multirow[b]{2}{*}{$\operatorname{Diet} \dagger \ldots$} & \multirow[b]{2}{*}{ Stock $1 \mathrm{~B}$} & \multirow[b]{2}{*}{$\begin{array}{c}\text { All rice } \\
2 \mathrm{~B}\end{array}$} & \multirow[b]{2}{*}{$\begin{array}{c}\text { Ricet } \\
\text { beans } \\
5 \mathrm{~B}\end{array}$} & \multirow[b]{2}{*}{$\begin{array}{l}\text { SE of } \\
\text { mean }\end{array}$} & \multicolumn{2}{|c|}{$\begin{array}{l}\text { Statistical } \\
\text { significance of } \\
\text { contrasts }\end{array}$} \\
\hline & & & & & $\begin{array}{l}\text { Diet } 1 \mathrm{~B} . \\
\text { (diet } 2 \mathrm{~B}+ \\
\operatorname{diet} 5 \mathrm{~B})\end{array}$ & $\begin{array}{c}\text { Diet 2B } v \\
\text { diet } 5 \mathrm{~B}\end{array}$ \\
\hline DM content of diet $(\mathrm{g} / \mathrm{kg})$ & 887 & 948 & 948 & - & - & - \\
\hline Growth rate $(\mathrm{g} / \mathrm{d}) \ddagger$ & $4 \cdot 2$ & 5.9 & 5.8 & 0.24 & $* * *$ & NS \\
\hline DM intake $\ddagger(g / d)$ & $13 \cdot 2$ & $14 \cdot 0$ & $14 \cdot 1$ & 0.09 & $* * *$ & NS \\
\hline $\begin{array}{l}\text { Faecal DM output } \$ \text { (g/kg } \\
\text { DM intake) }\end{array}$ & 266 & 45 & 76 & $2 \cdot 1$ & $* * *$ & $* * *$ \\
\hline Liver wt $(\mathrm{g} / \mathrm{kg}$ body wt) & $30 \cdot 6$ & $33 \cdot 3$ & $34 \cdot 2$ & 0.92 & * & NS \\
\hline
\end{tabular}

NS, not significant; DM, dry matter.

* $P<0.05$, *** $P<0.001$.

$\dagger$ For details, see Table 1 and p. 641.

$\ddagger$ Measured over days 15-26 of study.

Table 5. Expt B. Total caecal weight, caecal contents and tissue weights, pH of caecal contents and transit time through the caecum of rats given a stock diet and two experimental diets based on white rice with and without black-eye beans (Vigna unguiculata)

(Values are means with pooled standard errors for six rats per group)

\begin{tabular}{|c|c|c|c|c|c|c|}
\hline \multirow[b]{2}{*}{$\operatorname{Diet} \uparrow \ldots$} & \multirow[b]{2}{*}{$\begin{array}{c}\text { Stock } \\
1 \mathrm{~B}\end{array}$} & \multirow[b]{2}{*}{$\begin{array}{c}\text { All rice } \\
2 \mathrm{~B}\end{array}$} & \multirow[b]{2}{*}{$\begin{array}{c}\text { Rice }+ \\
\text { beans } \\
5 \mathrm{~B}\end{array}$} & \multirow[b]{2}{*}{$\begin{array}{l}\text { SE of } \\
\text { mean }\end{array}$} & \multicolumn{2}{|c|}{$\begin{array}{l}\text { Statistical } \\
\text { significance of } \\
\text { contrasts }\end{array}$} \\
\hline & & & & & $\begin{array}{c}\text { Diet } 1 \mathrm{~B} \nu \\
(\operatorname{diet} 2 \mathrm{~B}+ \\
\operatorname{diet} 5 \mathrm{~B})\end{array}$ & $\begin{array}{c}\text { Diet } 2 \mathrm{~B} v \\
\operatorname{diet} 5 \mathrm{~B}\end{array}$ \\
\hline Caecal wt (g) & $6 \cdot 15$ & $3 \cdot 14$ & 6.56 & $0 \cdot 337$ & $* *$ & $* * *$ \\
\hline Caecal contents dry wt (g) & $1 \cdot 27$ & 0.48 & 0.97 & 0.060 & $* * *$ & $* * *$ \\
\hline Caecal contents DM $(\mathrm{g} / \mathrm{kg})$ & 253 & 202 & 178 & 3.9 & $* * *$ & $* * *$ \\
\hline Caecal tissue wet wt $(\mathrm{g})$ & $1 \cdot 11$ & $0 \cdot 80$ & $1 \cdot 11$ & 0.054 & $*$ & $* * *$ \\
\hline Caecal pH & $5 \cdot 8$ & $6 \cdot 3$ & $5 \cdot 7$ & 0.07 & * & $* * *$ \\
\hline Caecal transit time $(\mathrm{h})$ & $7 \cdot 1$ & $19 \cdot 7$ & $20 \cdot 1$ & $1 \cdot 64$ & $* * *$ & NS \\
\hline
\end{tabular}

NS, not significant; DM, dry matter.

$* P<0.05, * * P<0.01$, *** $P<0.001$.

$\dagger$ For details, see Table 1 and p. 641.

lowest for the bean-containing diet (diet $5 \mathrm{~B}$ ), so that the dry weight of caecal contents was 2.6 and 1.3 times greater with diet $1 \mathrm{~B}$ than with diets $2 \mathrm{~B}$ and $5 \mathrm{~B}$ respectively. The $\mathrm{pH}$ of caecal contents was considerably higher in animals fed on the all-rice diet than in those fed on the other two diets, which both produced similar values (Table 5).

The proportion of ingested $\mathrm{Cr}_{2} \mathrm{O}_{3}$ recovered in faeces was high, with means of 1.00, 1.09 and 1.06 (SE 0.021 ) for diets $1 \mathrm{~B}, 2 \mathrm{~B}$ and $5 \mathrm{~B}$ respectively. The mean transit time of $\mathrm{Cr}_{2} \mathrm{O}_{3}$ 
Table 6. Expt B. Total volatile fatty acid (VFA) concentrations and molar proportions of individual VFA in caecal contents from rats given a stock diet and two experimental diets based on white rice with and without black-eye beans (Vigna unguiculata)

(Values are means with pooled standard errors for six rats per group)

\begin{tabular}{|c|c|c|c|c|c|c|}
\hline \multirow[b]{2}{*}{$\operatorname{Diet} \dagger \ldots$} & \multirow[b]{2}{*}{ Stock I B } & \multirow[b]{2}{*}{$\begin{array}{c}\text { All rice } \\
2 \mathrm{~B}\end{array}$} & \multirow[b]{2}{*}{$\begin{array}{c}\text { Rice }+ \\
\text { beans } \\
5 \mathbf{B}\end{array}$} & \multirow[b]{2}{*}{$\begin{array}{l}\mathrm{SE} \text { of } \\
\text { mean }\end{array}$} & \multicolumn{2}{|c|}{$\begin{array}{l}\text { Statistical } \\
\text { significance of } \\
\text { contrasts }\end{array}$} \\
\hline & & & & & $\begin{array}{c}\text { Diet } 1 \mathrm{~B} v \\
(\operatorname{diet} 2 \mathrm{~B}+ \\
\operatorname{diet} 5 \mathrm{~B})\end{array}$ & $\begin{array}{c}\text { Diet } 2 \mathrm{~B} v \\
\text { diet } 5 \mathrm{~B}\end{array}$ \\
\hline $\begin{array}{l}\text { Total VFA (mmol } / \mathrm{kg} \\
\text { caecal contents) } \\
\text { Molar proportions } \\
\text { of VFA ( } \mathrm{mmol} / \mathrm{mol})\end{array}$ & 114 & 140 & 154 & $6 \cdot 7$ & $* *$ & NS \\
\hline Acetate & 652 & 781 & 770 & $10 \cdot 9$ & $* * *$ & NS \\
\hline Propionate & 107 & 135 & 111 & $4 \cdot 9$ & $*$ & $* *$ \\
\hline Isobutyrate & 6 & 8 & 1 & $1 \cdot 0$ & NS & $* * *$ \\
\hline Butyrate & 214 & 55 & 99 & $11 \cdot 0$ & $* * *$ & $*$ \\
\hline Isovalerate & 9 & 10 & 6 & $0 \cdot 8$ & NS & $* *$ \\
\hline Valerate & 12 & 12 & 13 & 0.9 & NS & NS \\
\hline
\end{tabular}

NS, not significant.

$* P<0.05$, ** $P<0.01, \quad * * * P<0.001$.

$\dagger$ For details, see Table 1 and p. 641 .

in the caecum (estimated as total $\mathrm{Cr}_{2} \mathrm{O}_{3}$ in the caecum divided by the rate of $\mathrm{Cr}_{2} \mathrm{O}_{3}$ intake; see Faichney, 1975 and Goodlad \& Mathers, 1987) was similar for diets 2B and 5B, but was very much shorter for animals given the stock diet (Table 5).

There was no significant $(P>0.05)$ difference in the total VFA concentration in the caecum for the all-rice and rice + beans diets but, because of the greater caecal contents mass, the VFA pool size was $2 \cdot 6$ times greater for the bean-containing diet. Total VFA concentration in caecal contents was significantly $(P<0 \cdot 01)$ lower for the stock diet. The proportions of individual VFA were considerably influenced by diet, with a much lower proportion of acetate on diet $1 \mathrm{~B}$ than on diets $2 \mathrm{~B}$ and $5 \mathrm{~B}$. The proportion of propionate was highest for the all-rice diet and similar for the stock and rice + beans diets. Butyrate proportions were almost four times higher for diet $1 \mathrm{~B}$ than for diet $2 \mathrm{~B}$, with an intermediate value for diet $5 \mathrm{~B}$. After taking the caecal masses into account, the caecal butyrate pool sizes were 18,83 and $123 \mu \mathrm{mol} /$ rat for the all-rice, rice + beans and stock diets respectively. For the minor VFA, there were no significant differences between diets for valerate, but the rice + beans diet resulted in lower proportions of both iso-acids than either the stock or all-rice diets which were similar (Table 6).

\section{Faecal bacteriology}

Diet had no detectable effect on faecal concentrations of total anaerobes, whether facultative or obligate, but there were considerable between-diet differences for individual bacterial species (Table 7). Faecal concentrations of total Bacteroides, Bacteroides fragilis and Bacteroides vulgatus were similar for the stock and rice + beans diets but significantly lower for the all-rice diet. Fusobacterium sp. concentrations were significantly lower on the rice + beans diets compared with the all-rice diet. Veillonella sp. were also significantly lower on the all-rice diet. The latter diet was associated with higher concentrations of anaerobic Gram + ve rods and both rice-based diets (diets $2 \mathrm{~B}$ and $5 \mathrm{~B}$ ) resulted in higher 
Table 7. Bacterial concentrations in freshly voided faeces from rats given a stock diet and two experimental diets based on white rice with and without black-eye beans (Vigna unguiculata)

(Values are means with pooled standard errors for six rats per group)

\begin{tabular}{|c|c|c|c|c|c|c|}
\hline \multirow[b]{2}{*}{$\begin{array}{l}\text { Diet } \dagger \ldots \\
\text { Bacterial species }\end{array}$} & \multicolumn{3}{|c|}{$\begin{array}{l}\text { Mean } \log _{10} \text { colony- } \\
\text { forming units } / g\end{array}$} & \multirow[b]{2}{*}{$\begin{array}{l}\mathrm{SE} \text { of } \\
\text { mean }\end{array}$} & \multicolumn{2}{|c|}{$\begin{array}{l}\text { Statistical } \\
\text { significance of } \\
\text { contrasts }\end{array}$} \\
\hline & $\begin{array}{l}\text { Stock } \\
1 \mathrm{~B}\end{array}$ & $\begin{array}{l}\text { All } \\
\text { rice } \\
2 \mathrm{~B}\end{array}$ & $\begin{array}{c}\text { Rice } \\
+ \text { beans } \\
5 \mathrm{~B}\end{array}$ & & $\begin{array}{l}\text { Diet 1 B } v \text {. } \\
\text { (diet 2B } \\
+\operatorname{diet} 5 \mathrm{~B})\end{array}$ & $\begin{array}{l}\text { Diet } 2 \mathrm{~B} v \text {. } \\
\operatorname{diet} 5 \mathrm{~B}\end{array}$ \\
\hline Total anaerobes: facultative & $9 \cdot 2$ & $9 \cdot 4$ & 9.6 & $0 \cdot 11$ & NS & NS \\
\hline obligate & $8 . \overline{9}$ & $9 \cdot 0$ & $9 \cdot 3$ & $0 \cdot 10$ & NS & NS \\
\hline Total Bacteroides & $8 \cdot 7$ & $7 \cdot 7$ & 8.6 & $0 \cdot 14$ & $* *$ & $* * *$ \\
\hline Bacteroides fragilis & $8 \cdot 1$ & $7 \cdot 0$ & $8 \cdot 2$ & 013 & $* *$ & $* * *$ \\
\hline Bacteroides vulgatus & $8 \cdot 5$ & $7 \cdot 3$ & $8 \cdot 4$ & $0 \cdot 25$ & NS & ** \\
\hline Fusobacterium sp. & 688 & $7 \cdot 1$ & $5 \cdot 0$ & $0 \cdot 40$ & NS & $* *$ \\
\hline Veillonella sp. & $2 \cdot 5$ & $2 \cdot 0$ & $2 \cdot 8$ & $0 \cdot 23$ & NS & $*$ \\
\hline Bifidobacterium sp. & $7 \cdot 6$ & $8 \cdot 3$ & $8 \cdot 4$ & 0.19 & $* *$ & NS \\
\hline Eubacterium sp. & $6 \cdot 9$ & $6 \cdot 2$ & $7 \cdot 5$ & $0 \cdot 64$ & NS & NS \\
\hline Anaerobic Gram + ve rods & $6 \cdot 2$ & $8 \cdot 1$ & $4 \cdot 5$ & $0 \cdot 84$ & NS & $* *$ \\
\hline Clostridium sp. Lec + ve & $2 \cdot 7$ & $1 \cdot 9$ & $1 \cdot 6$ & 0.23 & $* *$ & NS \\
\hline Clostridium sp. Lec-ve & $4 \cdot 4$ & $3 \cdot 2$ & $2 \cdot 3$ & $0 \cdot 44$ & $* *$ & NS \\
\hline Lactobacillus sp. & $8 \cdot 3$ & $8 \cdot \overline{3}$ & $8 \cdot 4$ & $0 \cdot 13$ & NS & NS \\
\hline Total aerobes & $7 \cdot 8$ & $8 \cdot 9$ & $9 \cdot 2$ & $0 \cdot 18$ & $* * *$ & NS \\
\hline Enterobacteria & 6.5 & $7 \cdot 7$ & $7 \cdot 9$ & $0 \cdot 29$ & $* *$ & NS \\
\hline Enterococci & $5 \cdot 8$ & $7 \cdot 0$ & $6 \cdot 7$ & $0 \cdot 32$ & $*$ & NS \\
\hline
\end{tabular}

Lec + ve, lecithinase-positive; Lec-ve, lecithinase-negative; NS, not significant.

* $P<0.05, \quad * * P<0.01$, *** $P<0.001$.

$\dagger$ For details, see Table 1 and p. 640 .

faecal concentrations of Bifidobacterium sp. and aerobic species. Both lecithinase-positive and lecithinase-negative clostridia were present in higher concentrations in faeces from stock-fed rats than in those given the rice-based diets. Counts of Lactobacillus sp. were similar for all three diets (Table 7).

\section{DISCUSSION}

The occurrence of vitamin $\mathrm{K}$ deficiency symptoms in Expt A was unexpected since the rat is usually considered to be fairly resistant to the development of vitamin $\mathrm{K}$ deficiency. Deficiency has occurred in animals given diets low in phylloquinone when coprophagy is prevented (Barnes \& Fiala, 1959; Mameesh \& Johnson, 1959) or when rats are reared germfree (Gustafsson, 1959). Administration of antibiotics to rats (Kornberg et al. 1944; Matschiner \& Doisy, 1965) or man (O'Reilly, 1971; Allison et al. 1987) has been used to reduce enteric menaquinone production in studies of vitamin $\mathrm{K}$ depletion, and the clinical appearance of vitamin $\mathrm{K}$ deficiency is sometimes associated with antibiotic use (Pineo et al. 1973; Colvin \& Lloyd, 1977; Hooper et al. 1980; Krasinski et al. 1985). Such findings together with the presence of menaquinones in some species of enteric anaerobes (Collins \& Jones, 1981 ; see Table 8) and the possibility that menaquinones could be absorbed across the large-intestinal mucosa (Hollander et al. 1976) suggest, but do not prove, that enterically produced menaquinones are an important source of vitamin $\mathrm{K}$ activity. Among the factors which could have contributed to the appearance of vitamin $\mathrm{K}$ deficiency symptoms in rats given diet $2 \mathrm{~A}$ are (1) low dietary phylloquinone concentration (Table 2); (2) low production of menaquinones by the large-intestinal bacteria because of limited 
Table 8. Menaquinones $(M K)$ produced by the main species of the enteric flora*

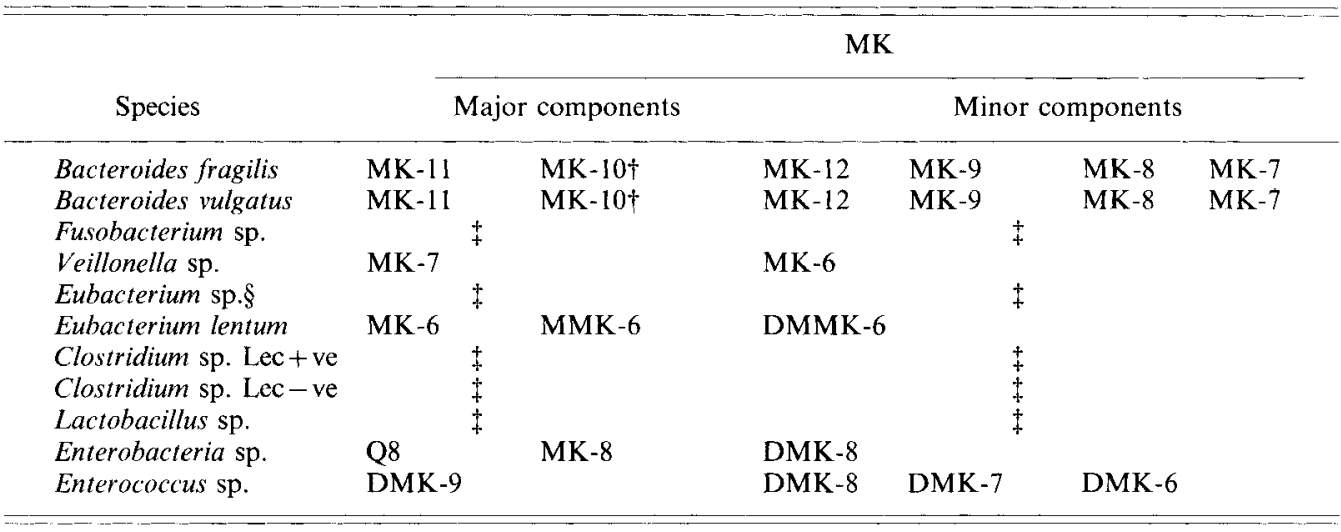

Q-n, ubiquinone; MK-n, menaquinone; DMK-n, demethylmenaquinone; MMK-n, methylmenaquinone; DMMK- $n$, dimethylmenaquinone, where $n$ indicates the number of isoprene units in the side-chain; Lec $+v e$, lecithinase positive, Lec-ve, lecithinase-negative.

* Data from Collins \& Jones (1981), Collins et al. (1985) and Fernandez \& Collins (1987).

$\dagger$ Present in comparable amounts.

† Lacks MK.

$\S$ Except Eubacterium lentum.

supply of fermentable substrate to the large intestine from this very-low-fibre diet, coupled with the proliferation of a flora in which menaquinone-producers were in a minority; and (3) failure to absorb sufficient menaquinones directly from the large bowel or indirectly from the small intestine after coprophagy. The rats in the present study were housed in metabolism cages with expanded metal floors, which although not completely preventing consumption of faeces reduces this to a relatively insignificant amount (J. C. Mathers, unpublished results; see also Uchida \& Komeno, 1988).

Measurements on freshly voided faeces showed that quite different floras were established in animals given the stock diet (1 B), the all-rice diet $(2 \mathrm{~B})$ and the rice + beans diet $(5 \mathrm{~B})$ (see Table 7). The menaquinone profiles of the main enteric species found in the present study are listed in Table 8. Kindberg et al. (1987) inoculated different groups of germ-free rats with groups of organisms which were known to produce menaquinones (Bacteroides vulgatus and Escherichia coli) or did not produce menaquinones (Bifidobacterium longum and Clostridium ramosum). They did not detect menaquinones in the faeces or livers from animals given the latter two inoculants, but rats colonized with Bacteroides vulgatus had high concentrations of menaquinone MK-10 and significant amounts of MK-9 and MK11 in faeces, whilst the $E$. coli-inoculated rats had MK-8 and MK-7 as major faecal menaquinones. Liver concentrations of menaquinones mirrored faecal concentrations and were higher in animals housed in wire-bottomed cages than in those in cages designed to prevent coprophagy. These findings demonstrate (1) that the predominant menaquinones of enteric bacteria grown in vivo are the same as those reported from pure-culture studies (Collins \& Jones, 1981; Ramotar et al. 1984) and (2) that these menaquinones may be absorbed and appear in the liver (and, therefore, are a potential source of vitamin $K$ activity). The results do not clarify to what extent coprophagy is necessary for efficient absorption. Faeces from animals given diet $2 \mathrm{~B}$ had significantly reduced concentrations of the main menaquinone producers, i.e. Bacteroides fragilis and Bacteroides vulgatus (Table 7) and this coupled with the very low faecal output on this diet (Table 4) suggests that total enteric menaquinone production was low for animals given the all-rice diets ( $2 \mathrm{~A}$ and $2 \mathrm{~B}$ ). 

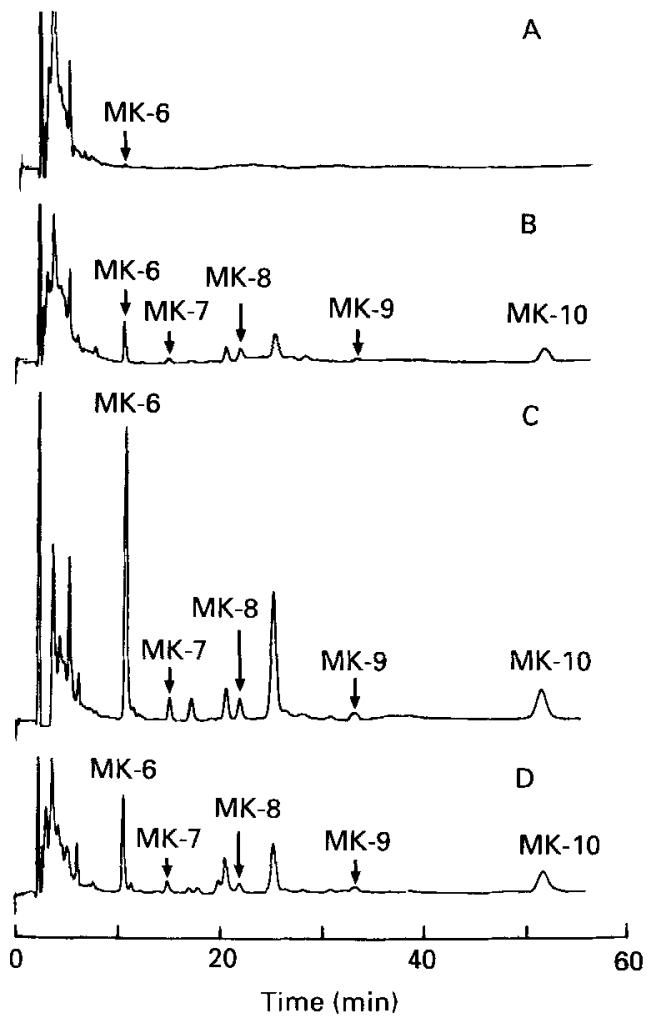

Fig. 1, Expt 1. Chromatograms illustrating the menaquinone (MK) profiles in the livers of four representative rats (A to D) given experimental diets $2 \mathrm{~A}$ to $5 \mathrm{~A}$ respectively. The rat numbers, liver phylloquinone $\left(\mathrm{K}_{1}\right)$ concentrations and prothrombin times (PT) are given below in parenthesis.

A. Diet $2 \mathrm{~A}$ (rat 36 , liver $\mathrm{K}_{1} 0 \cdot 13 \mathrm{ng} / \mathrm{g}, \mathrm{PT}>60 \mathrm{~s}$ ).

B. Diet $3 \mathrm{~A}$ (rat 21 , liver $\mathrm{K}_{1} 0.36 \mathrm{ng} / \mathrm{g}, \mathrm{PT} 24 \mathrm{~s}$ ).

C. Diet $4 \mathrm{~A}$ (rat 19 , liver $\mathrm{K}_{1} 0.52 \mathrm{ng} / \mathrm{g}, \mathrm{PT} 15 \mathrm{~s}$ ).

D. Diet $5 \mathrm{~A}$ (rat 18 , liver $\mathrm{K}_{1} 0.33 \mathrm{ng} / \mathrm{g}, \mathrm{PT} 15 \mathrm{~s}$ )

Initial results of menaquinone measurements on the livers from rats from Expt $\mathrm{A}$ indicate very much lower concentrations of menaquinone when the all-rice diet ( $2 \mathrm{~A})$ was given than when bean-containing diets were eaten.

Chromatograms of hepatic menaquinones in four representative rats each given one of the four experimental diets $(2 \mathrm{~A}-5 \mathrm{~A})$ are shown in Fig. 1. Two of these rats (nos. 36 and 21) were vitamin $\mathrm{K}$-deficient as evidenced by the prolonged prothrombin times and low levels of individual vitamin $\mathrm{K}$-dependent clotting factors (Table 3 ). The most severely vitamin $\mathrm{K}$-deficient rat (no. 36) with a prothrombin time of $>60 \mathrm{~s}$ had been given the allrice diet and had both the lowest liver phylloquinone concentration $(0 \cdot 13 \mathrm{ng} / \mathrm{g})$ and no detectable menaquinones apart from a trace of MK-6 (Fig, 1 A). Rat no. 21 with a prothrombin time prolonged to $24 \mathrm{~s}$ also showed evidence of lower hepatic MK-6 and MK10 concentrations (Fig. 1 B) compared with rats fed on diets containing a higher proportion of beans (Fig. 1 C, D).

The reasons for the altered faecal flora observed here are uncertain. Classical studies in man (see Moore \& Holdeman, 1975; for review, see Borriello, 1986) have indicated that whilst there is considerable inter-person variability, the faecal flora of an individual is stable and not readily changed by dietary means. However, the metabolic activity of the large- 
bowel flora is influenced by diet. For example, the polysaccharide-degrading systems of Bacteroides appear to be inducible in vitro (Salyers, et al. 1985), and Wyatt et al. (1986) have reported a rapid increase in the numbers of faecal flora able to degrade gum arabic after this polymer was included in the diet of a human volunteer. Several studies have shown that dietary manipulation changes the pattern of VFA which are the major fermentation end-products of enteric bacteria (Horn et al. 1986; Cheng et al. 1987; Key \& Mathers, 1987). Marked changes in VFA pattern were also observed in Expt B (see Table 6). Inclusion in the diets of rats of fibre sources such as pectin, or of starches which are resistant to small-intestinal digestion may alter the activities of enzymes such as nitrate reductase ( $E C$ 1 1.7.99.4) in faecal samples (Mallett et al. 1987), and $\beta$-glucuronidase ( $E C$ 3.2.1.31) and nitroreductase in caecal contents (Mallett et al. 1988). Oral administration of antibiotics such as bacitracin and erythromycin alter the pattern of VFA in human faeces (Hoverstad et al. 1986), whilst the growth-promoting antibiotic Avoparcin alters caecal VFA in rats (Mathers \& Finlayson, 1989). Dietary manipulation may provoke changes in VFA end-products because of alterations in substrates flowing to the large bowel (Goodlad \& Mathers, 1988) and alterations in the environmental conditions of the large intestine such as $\mathrm{pH}$ or transit time. The results in Table 5 show that those diets which would be expected to supply the greater amounts of substrate to the large bowel (diets $1 \mathrm{~B}$ and $5 \mathrm{~B}$ ) resulted in larger caecal masses and lower $\mathrm{pH}$. Diet $1 \mathrm{~B}$ which contained the greatest proportion of indigestible material was associated with very short caecal transit times, which is likely to have increased the selective pressure on the caecal flora. It is likely that it was the differences in amounts and types of dietary carbohydrate which were responsible for the changes in both flora and fermentation end-products observed in the present study. Addition of wheat bran to a maize-based diet resulted in significant changes in the faecal flora of pigs, whilst addition of maize oil had no effect (Moore et al. 1987). Similarly replacement of white by wholemeal bread in the diet of rats provoked large changes in caecal VFA patterns (Key \& Mathers, 1987) which were unaffected by dietary oil concentration (Key \& Mathers, 1988).

Since the present study was completed, a report has appeared by Uchida \& Komeno (1988) who compared menaquinone concentrations in intestinal contents and liver and who concluded that 'menaquinones do not seem to play a significant role in clotting factor synthesis in rats'. In contrast, Ramotar et al. (1988) reported that rats fed on cooked ricebased diets (O'Reilly, 1971) had lower concentrations of phylloquinone in blood and liver when compared with chow-fed animals, but prothrombin clotting time was increased and caecal menaquinone concentrations reduced only when animals received subcutaneous injections of the antibiotic moxolactam. Ramotar et al. (1988) concluded that 'diets have a major effect upon intestinal menaquinone profiles, and secondarily (sic) may alter intrahepatic stores of vitamin (K)'. The effectiveness of intestinally-derived menaquinones as a source of vitamin $\mathrm{K}$ remains controversial. However, our study has shown that dietary modification using normal foods may alter the potential vitamin $\mathrm{K}$ supply from enteric bacterial menaquinones by altering the density of large-bowel menaquinone-producing bacteria. Further work is needed to explain the reasons for such changes.

The authors thank Janet Devoy, Veterinary Investigation Centre, Longbenton, Newcastle upon Tyne for post-mortem examination of the rats from Expt A.

Allison, P. M., Mummah-Schendel, L. L., Kindberg, C. G., Harms, C. S., Bang, N. U. \& Suttie, J. W. (1987). Effects of a vitamin K-deficient diet and antibiotics in normal human volunteers. Journal of Laboratory and Clinical Medicine 110, 180-188. 
Barnes, R. H. \& Fiala, G. (1959). Effects of the prevention of coprophagy in the rat. VI. Vitamin K. Journal of Nutrition 68, 603-614.

Black, S., Overman, R. S., Elvehjem, C. A. \& Link, K. P. (1942). The effect of sulfaguanidine on rat growth and plasma prothrombin. Journal of Biological Chemistry 145, 137-143.

Borricllo, S. P. (1986). Microbial flora of the gastrointestinal tract. In Microbial Metabolism in the Digestive Tract, pp. 1-19 [M. J. Hill, editor]. Boca Raton, Florida: CRC Press Inc.

Borriello, S. P., Hudson, M. \& Hill, M. (1978). Investigation of the gastrointestinal bacterial flora. Clinics in Gastroenterology 7, 329-349.

Bullen, C. L., Tearle, P. V. \& Stewart, M. G. (1977). The effect of 'humanized' milks and supplemented breast feeding on the faecal flora of infants. Journal of Medical Microbiology 10, 403-4I3.

Cheng, B.-Q., Trimble, R. P., Illman, R. J., Stone, B. A. \& Topping, D. L. (1987). Comparative effects of dietary wheat bran and its morphological components (aleurone and pericarp-seed coat) on volatile fatty acid concentrations in the rat. British Journal of Nutrition 57, 69-76.

Collins, M. D., Fernandez, F., \& Howarth, O. W. (1985). Isolation and characterization of a novel vitamin-K from Eubacterium lentum. Biochemical and Biophysical Research Communications 133, 322-328.

Collins, M. D. \& Jones, D. (1981). Distribution of isoprenoid quinone structural types in bacteria and their taxonomic implications. Microbiological Reviews 45, 316-354.

Colvin, B. T. \& Lloyd, M. J. (1977). Severe coagulation defect due to a dietary deficiency of vitamin K. Journal of Clinical Pathology 30, 1147-1 148.

Cowan, S. T. \& Steel, K, J. (1965). Manual for Identification of Medical Bacteria. Cambridge: Cambridge University Press.

Faichney, G. J. (1975). The use of markers to partition digestion within the gastro-intestinal tract of ruminants. In Digestion and Metabolism in the Ruminant, pp. 277-291 [I. W. McDonald and A. C. I. Warner, editors]. Armidale: University of New England Publishing Unit.

Fernandez, F. \& Collins, M. D. (1987). Vitamin K composition of anacrobic gut bacteria. FEMS Microbiological Letlers 41, 175-180.

Goodlad, J. S. \& Mathers, J. C. (1987). Digesta flow from the ileum and transit time through the caecum of rats given diets containing graded levels of peas. Proceedings of the Nutrition Society 46, 149A.

Goodlad, J. S. \& Mathers, J. C. (1988). Effects of food carbohydrates on large intestinal fermentation in vitro. Proceedings of the Nutrition Society 47, 176A.

Gustafsson, B. E. (1959). Vitamin K deficiency in germfree rats. Annals of the New York Academy of Sciences 78. $166-174$

Haroon, Y., Shearer, M. J., Rahim, S., Gunn, W. G., McEnery, G. \& Barkhan, P. (1982). The content of phylloquinone (vitamin $\mathrm{K}_{1}$ ) in human milk, cows milk and infant formula foods determined by highperformance liquid chromatography. Journal of Nutrition 112, 1105-1117.

Hart, J. P., Shearer, M. J. \& McCarthy, P. T. (1985). Enhanced sensitivity for the determination of endogenous phylloquinone (vitamin $\mathrm{K}_{1}$ ) in plasma using high-performance liquid chromatography with dual-electrode electrochemical detection. Analyst 110, 1181-1184

Holdeman, L. V., Cato, E. P. \& Moore, W. E. (1977). Anaerobe Laboratory Manual, 4th ed. Blacksburg, Virginia : Virginia Polytechnic Institute.

Hollander, D., Muralidhara, K. S. \& Rim, S. (1976). Colonic absorption of bacterially synthesized vitamin $\mathrm{K}_{2}$ in the rat. American Journal of Physiology 230, 251-255.

Hooper, C. A., Haney, B. B. \& Stone, H. H. (1980). Gastrointestinal bleeding due to vitamin K deficiency in patients on parenteral cefamandole. Lancet i, 39-40.

Horn, N., Wyatt, G. M., Bayliss, C. E., Gee, J. M. \& Johnson, I. T. (1986). The effect of dietary fibre on bacterial densities in the rat intestine. Food Microbiology 3, 295-302.

Hoverstad, T., Carlstedt-Duke, B, Lingaas, E., Norin, E., Saxerholt, H., Steinbakk, M. \& Midtvedt, T. (1986). Influence of oral intake of seven different antibiotics on faecal short-chain fatty acid excretion in healthy subjects. Scandinavian Journal of Gastroenterology 21, $997 \cdot 1003$.

Key, F. B. \& Mathers, J. C. (1987). Response of rat caecal metabolism to varying proportions of white and wholemeal breads. Proceedings of the Nutrition Society 46, $11 \mathrm{~A}$.

Key, F. B. \& Mathers, J. C. (1988). Reponse of rat caecal metabolism to white and wholemeal breads given at two fat levels. Proceedings of the Nutrition Society 47, 101A.

Kindberg, C., Suttie, J. W., Uchida, K., Hirauchi, K. \& Nakao, H. (1987). Menaquinone production and utilization in germ-free rats after inoculation with specific organisms. Journal of Nutrition 117, 1032-1035.

Kornberg, A., Daft, F. S. \& Sebrell, W. H. (1944). Mechanism of production of vitamin K deficiency in rats by sulfonamides. Journal of Biological Chemistry 155, 193-200.

Krasinski, S. D., Russell, R. M., Furie, B. C., Kruger, S. F., Jacques, P. F. \& Furie, B. (1985). The prevalence of vitamin $\mathrm{K}$ deficiency in chronic gastrointestinal disorders. American Journal of Clinical Nutrition 41, 639-643.

Mallett, A. K., Bearne, C. A., Rowland, I. R., Farthing, M. J. G., Cole, C. B. \& Fuller, R. (1987). The use of rats associated with a human faecal fiora as a model for studying the effects of diet on the human gut microflora. Journal of Applied Bacteriology 63, 39-45.

Mallett, A. K., Bearne, C. A., Young, P. J., Rowland, I. R. \& Berry, C. (1988). Influence of starches of low digestibility on the rat caccal microflora. British Journal of Nutrition 60, 597-604. 
Mameesh, M. S. \& Johnson, B. C. (1959). Production of dietary vitamin K deficiency in the rat. Proceedings of the Society for Experimental Biology and Medicine 101, 467-468.

Mathers, J. C. \& Finlayson, H. J. (1989). Manipulation of rat caecal metabolism by including Avoparcin and pectin in the diet. Proceedings of the Nutrition Society 48, 139A.

Matschiner, J. T. \& Doisy, E. A. Jr (1965). Effect of dietary protein on the development of vitamin K deficiency in the rat. Journal of Nutrition 86, 93-99.

Moore, W. E. C. \& Holdeman, L. V. (1975). Discussion of current bacteriological investigations of the relationships between intestinal flora, diet and colon cancer. Cancer Research 35, 3418-3420.

Moore, W. E. C., Moore, L. V. H., Cato, E. P., Wilkins, T. D. \& Kornegay, E. T. (1987). Effect of high-fiber and high-oil diets on the faecal flora of swine. Applied and Environmental Microbiology 53, 1638-1644.

National Research Council (1978). Nutrient Requirements of Laboratory Animals, no. 10, 3rd ed. Washington, DC: National Academy of Sciences.

O'Reilly, R. A. (1971). Vitamin K in hereditary resistance to oral anticoagulant drugs. American Journal of Physiology 221, 1327 1330.

Passmore, R. \& Eastwood, M. A. (1986). Davidson and Passmore Human Nutrition and Dietetics, 8th ed. Edinburgh: Churchill Livingstone.

Paul, B., Oxley, A., Brigham, K., Cox, T. \& Hamilton, P. J. (1987). Factor II, VII, IX and X concentrations in patients receiving long-term warfarin. Journal of Clinical Pathology 40, 94-98.

Pineo, G. F., Gallus, A. S. \& Hirst, J. (1973). Unexpected vitamin K deficiency in hospitalized patients. Canadian Medical Association Journal 109, 880883.

Ramotar, K., Conly, J. M., Chubb, H. \& Louie, T. J. (1984). Production of menaquinones by intestinal anaerobes. Journal of Infectious Diseases 150, 213-218.

Ramotar, K., Krulicki, W., Gray, G. \& Louie, T. (1988). Studies on intestinal and hepatic concentrations of menaquinone and hypoprothrombinemia in vitamin $\mathrm{K}_{1}$-deficient rats. In Current Advances in Vitamin $K$ Research, pp. 493-498 [J. W. Suttie, editor]. New York: Elsevier.

Salyers, A. A., Kuritza, A. P. \& McCarthy, R. E. (1985). Influence of dietary fiber on the intestinal environment. Proceedings of the Society for Experimental Biology and Medicine 180, 415-421.

Shearer, M. J. (1986a). Assay of K vitamins in tissues by high-performance liquid chromatography with special reference to ultraviolet detection. Methods in Enzymology 123, 235-251.

Shearer, M. J. (1986 b). Vitamins. In HPLC of Small Molecules: A Practical Approach, pp. 157-219 [C. K. Lim, editor]. Oxford: IRL Press.

Shearer, M. J., Barkham, P., Rahim, S. \& Stimmler, L. (1982). Plasma vitamin $K_{1}$ in mothers and their newborn babies. Lancet ii, $460-463$.

Suttie, J. W. (1985). Vitamin K. In The Fat-soluble Vitamins, pp. 225-311 [A. T. Diplock, editor]. London: William Heinemann Ltd.

Thompson, A. (1970). Rat metabolism cage. Journal of the Institute of Animal Technicians 21, 15-21.

Uchida, K. \& Komeno, T. (1988). Relationships between dietary and intestinal vitamin K, clotting factor levels, plasma vitamin $\mathrm{K}$ and urinary Gla. In Current Advances in Vitamin K Research, pp. 477-492 [J. W. Suttie, editor]. New York: Elsevier.

Von Kries, R., Shearer, M. J. \& Göbel, U. (1988). Vitamin K in infancy. European Journal of Pediatrics 147, 106112.

Wyatt, G. M., Bayliss, C. E. \& Holcroft, J. D. (1986). A change in human faecal flora in response to inclusion of gum arabic in the diet. British Journal of Nutrition 55, 261-266. 